\title{
Cisplatin combined with laser-activated nanotherapy as an adjuvant therapy for head and neck cancer
}

\author{
GEE YOUNG LEE ${ }^{1,2^{*}}$, JONTÉ A. MYERS ${ }^{3}$, SANDRA M. PEREZ $^{4}$, KARAN P. SINGH $^{4}$ and HADIYAH N. GREEN ${ }^{1,2,5^{*}}$ \\ ${ }^{1}$ Department of Surgery, Morehouse School of Medicine, Atlanta, GA 30310; ${ }^{2}$ Biomedical Laboratory Research and \\ Development Service, Office of Research and Development, US Department of Veterans Affairs, \\ Birmingham VA Medical Center, Birmingham, AL 35233; ${ }^{3}$ Department of Learning Sciences, College of Education and \\ Human Development, Georgia State University, Atlanta, GA 30303; ${ }^{4}$ Department of Epidemiology and Biostatistics, \\ School of Community and Rural Health, The University of Texas Health Science Center at Tyler, Tyler, TX 75708; \\ ${ }^{5}$ Ora Lee Smith Cancer Research Foundation, Advanced Technology and Development Center, Atlanta, GA 30308, USA
}

Received April 6, 2020; Accepted July 23, 2020

DOI: $10.3892 /$ ijo.2020.5126

\begin{abstract}
Head and neck cancers (HNCs), in general, have a poor prognosis with a worldwide 5-year survival rate of $<50 \%$. Numerous HNC patients with locoregionally advanced, difficult-to-treat, inoperable, recurrent and drug-resistant tumors may require additional treatment options when the standard of care surgery, chemotherapy and radiation are not viable. The poor outcomes justify exploring strategies to increase the efficacy of lower doses of drugs, such as cisplatin, by combining these drugs with other treatment modalities and manipulating the dosing schedule. Cisplatin is a standard and effective anticancer drug; however, some patients cannot tolerate the side-effects or exhibit drug resistance. Adjuvant therapies may lower the effective dose, decrease side-effects, address drug resistance and improve overall survival outcomes, particularly for patients with difficult-to-treat tumors. The present study focuses on combining cisplatin with laser-activated nanotherapy (LANT), as an adjuvant HNC therapy, with the aim of enhancing the therapeutic efficacy of lower doses of cisplatin and decreasing treatment times. The results demonstrate the potential of cisplatin and LANT co-therapy as a possible addition to the adjuvant therapy options for HNC using 3 cell lines: Detroit 562, FaDu and CAL 27 cells. Combining
\end{abstract}

Correspondence to: Dr Hadiyah N. Green, Ora Lee Smith Cancer Research Foundation, Advanced Technology and Development Center, Atlanta, GA 30308, USA

E-mail: drgreen@oralee.org

* Contributed equally

Abbreviations: AuNRs, gold nanorods; AuNPs, gold nanoparticles; NPs, nanoparticles; LANT, laser-activated nanotherapy; Cis, cisplatin; HNC, head and neck cancer; HNSCC, head and neck squamous cell carcinoma

Key words: cisplatin, low dose, combination therapy, gold nanorods, lasers, nanotherapy, adjuvant therapy cisplatin with LANT demonstrated up to a 5.4-fold greater therapeutic efficacy than with cisplatin monotreatment. The most effective combination in the present study was $1 \mu \mathrm{M}$ Cis $+5 \mathrm{nM}$ LANT, which demonstrated cell death comparable to 5.9, 4.2 and $5.3 \mu \mathrm{M}$ of $\mathrm{Cis}$ monotreatment, in Detroit 562, FaDu and CAL 27 cells, respectively. This result suggests that a lower cisplatin dose may be combined with LANT to achieve the same therapeutic efficacy as that obtained with higher doses of cisplatin monotreatment. The combination of LANT and cisplatin suggests that LANT may enhance the therapeutic efficiency of low doses of cisplatin, decrease treatment times and improve patient outcomes.

\section{Introduction}

Head and neck cancers (HNCs), in general, have a poor prognosis with a worldwide 5-year survival rate of $<50 \%(1-3)$. In part, this prognosis is due to the fact that numerous HNC patients with locoregionally advanced, difficult-to-treat, inoperable, recurrent and drug-resistant tumors may be ineligible for the standard of care surgery or may not tolerate chemotherapy and radiation (3-6). As a standard of care therapy, cisplatin is a primary treatment for HNC, breast, cervical, bladder, brain and other cancers. However, some patients do not tolerate the current standard dose regimen and exhibit increased side-effects or drug resistance (5-8).

Cisplatin, an antineoplastic or anticancer drug, binds to DNA purine bases and interferes with the cellular repair mechanisms, irreparably damaging the DNA and subsequently inducing apoptosis in the cell $(8,9)$. This approach does not limit cell death to the locoregional area of the tumor. Consequently, normal tissue and healthy cells throughout the body are also affected, resulting in one of the biggest patient-centered challenges with cisplatin: side effects. Not all patients will experience all of the known or listed side-effects, but some of the most common side-effects include nausea, vomiting, nephrotoxicity and ototoxicity, with the latter two being the most severe (10-12).

The severity of some of these side-effects prevents the more widespread use of cisplatin (11-13). Additional complications 
with this form of treatment are the possibility of drug resistance, aggressive recurrence and metastasis $(3,11,14,15)$. Following the onset of drug resistance, these patients usually do not survive past one year $(6,16,17)$. Poor survival rates and outcomes are among the reasons that the scientific community is beginning to explore strategies to increase the efficacy of cisplatin at lower doses by combining it with other treatment modalities and manipulating the dosing schedule $(6,10,18-21)$. Dosing typically depends on the patient's height, weight, general health and any specific health condition. The standard cisplatin dose and schedule are usually 3 cycles of $100 \mathrm{mg} / \mathrm{m}^{2}$ every 3 to 4 weeks when used individually as a monotreatment for HNC patients (22-24). Recent studies on manipulating the cisplatin dosage have compared high-dose cisplatin with a cisplatin-based combination therapy (radiation, chemotherapy, or other intervention) to decrease side-effects, increase treatment efficacy and improve patient outcomes and overall survival rates $(8,10,11,21,24-27)$.

Nanoparticles and nanomaterials have been used in the treatment of cancer to enhance targeted drug delivery and tumor specificity to minimize side-effects (28-32). The present study focuses on a particular class of laser-activated nanoparticles, specifically, a thermal ablation platform therapy using near-infrared excitation of gold nanorods (AuNRs), laser-activated nanotherapy (LANT). This LANT platform is not designed to enhance targeting, but specifically to induce cell death at the site of laser-activation for the sole purpose of its therapeutic effect. LANT has demonstrated almost $100 \%$ cell death in vitro and approximately $100 \%$ tumor regression in vivo (33). However, to the best of our knowledge, no such platform has been approved by the U. S. Food and Drug Administration (FDA) for humans to date. LANT presents an opportunity to override some of the biological obstacles encountered within the tumor microenvironment and with cisplatin specificity, efficacy, and treatment time. The present study investigates the mechanisms through which LANT, as part of an adjuvant therapy regimen, can enhance the therapeutic efficacy of lower doses of cisplatin for the treatment of 3 head and neck squamous cell carcinoma (HNSCC) cell lines, Detroit 562, FaDu and CAL 27.

\section{Materials and methods}

Materials. Gold (III) chloride trihydrate $\left(\mathrm{HAuCl}_{4}\right)$, cetyltrimethylammonium bromide (CTAB), sodium borohydride $\left(\mathrm{NaBH}_{4}\right)$, silver nitrate $\left(\mathrm{AgNO}_{3}\right)$, L-ascorbic acid, potassium carbonate $\left(\mathrm{K}_{2} \mathrm{CO}_{3}\right)$ and dimethyl sulfoxide (DMSO) were purchased from Sigma-Aldrich; Merck KGaA. Thiol-terminated methoxy poly-(ethylene glycol) (mPEG-SH, MW 5,000K) and cisplatin were purchased from Creative PEGWorks and Selleck Chemicals, respectively. UltraPure water (18 M $\Omega$ ) was used for gold nanorod preparation.

Cell lines. In total, 3 human HNSCC cell lines were used in this study: a human pharyngeal carcinoma cell line, Detroit 562 , and 2 human squamous cell carcinoma cell lines, $\mathrm{FaDu}$ and CAL 27. The cell lines were purchased from the American Type Culture Collection (ATCC). Upon receiving the cell lines from ATCC, the passage number was set at one and cells at passage 3-7 were used. The cells tested negative for mycoplasma. The HNSCC cell lines were cultured in Dulbecco's modified Eagle medium (DMEM; Gibco; Thermo Fisher Scientific, Inc.) containing $10 \% \mathrm{v} / \mathrm{v}$ heat-inactivated fetal bovine serum (Corning, Inc.), supplemented with $4.5 \mathrm{~g} / 1$ glucose, L-glutamine and penicillin-streptomycin (Corning, Inc.) and incubated at $37^{\circ} \mathrm{C}$ in a $5 \% \mathrm{CO}_{2}$ humidified atmosphere.

Cell death calculation from cell viability. Cell viability was determined using PrestoBlue ${ }^{\mathrm{TM}}$ Cell Viability Reagent (Thermo Fisher Scientific, Inc.). Briefly, the culture medium containing AuNRs or the drug was removed and replaced with culture medium containing PrestoBlue ${ }^{\mathrm{TM}}$ Cell Viability Reagent $(10 \% \mathrm{v} / \mathrm{v})$ and the cells were incubated at $37^{\circ} \mathrm{C}$ for $30 \mathrm{~min}$. The plate was read at a $560 / 590 \mathrm{~nm}$ excitation/emission wavelength using the SpectraMax ${ }^{\circledR}$ M5 Microplate Reader (Molecular Devices, LLC). The fluorescence reading of the blank was subtracted from all samples. The fluorescence readings from the test samples were divided by those of the control and multiplied by 100 to yield the percentage of cell viability. The percentage of cell death was then calculated by subtracting the percentage of cell viability from $100 \%$ (see formula below). The results are expressed as the means \pm standard deviation of sextuplet $(n=6)$ in each treatment group.

$\%$ of cell death $=100-\%$ cell viability

$$
=100-\frac{(\text { fluorescence of sample }- \text { fluorescence of blank })}{(\text { fluorescence of control }- \text { fluorescence blank })} \times 100
$$

Preparation of AuNRs. The seed-mediated growth of AuNRs was performed at $25^{\circ} \mathrm{C}$ using a freshly prepared aqueous solution according to our previously described methods, Green et al (34). Briefly, the PEGylated AuNRs solution was centrifuged at 7,600 x g for $20 \mathrm{~min}$ at $25^{\circ} \mathrm{C}$ and re-dispersed in deionized water to remove excess CTAB and non-specifically bound mPEG-SH molecules. The PEGylated AuNRs were characterized by UV/VIS Spectrophotometer UV5Nano (Mettler Toledo, LLC) to determine the absorption and by Transmission Electron Microscope to verify consistency in shape and size. The zeta-potential of the AuNRs in PBS were evaluated using a Zetasizer Nano-ZS (Malvern Panalytical, Ltd.).

LANT in vitro. LANT was performed according to our previously described methods, Green et al (34). A total of $6 \times 10^{4}$ cells/well were seeded in 96-well culture plates and treated at approximately $100 \%$ confluence. The concentration of the AuNRs were calculated by the Beer-Lambert Law based on the previously determined molar absorptivity, $\varepsilon=5$ $\mathrm{x} 10^{9} \mathrm{l} / \mathrm{mol} / \mathrm{cm}$ for $808 \mathrm{~nm}$ and aspect ratio, $\mathrm{R}=4$ (34). Serially diluted AuNRs $(25 \mu \mathrm{l})$ were added to each well and exposed to a diode near-infrared (NIR) laser (Information Unlimited) with an $808 \mathrm{~nm}$ wavelength at $1.875 \mathrm{~W} / \mathrm{cm}^{2}$ (spot size around $4 \mathrm{~mm}$ ) for $4 \mathrm{~min}$. Immediately, within 1-5 min after the laser excitation of the AuNRs, the percentage of cell death was determined by the PrestoBlue Assay, as described above.

Cell death induced by cisplatin. The HNSCC cell lines, Detroit 562, FaDu and CAL 27, were seeded in 96-wells plates at $1 \times 10^{4}$ cells/well and allowed to adhere overnight. The culture medium was then replaced with fresh medium containing 
cisplatin at various concentrations, $0.05-40 \mu \mathrm{M}$, and the cells were incubated at $37^{\circ} \mathrm{C}$ for $48 \mathrm{~h}$. The percentage of cell death was determined by the PrestoBlue Assay, as described above.

Combination of cisplatin and LANT in vitro. The HNSCC cell lines were seeded in 96-wells plates at $1 \times 10^{4}$ cells/well and allowed to adhere overnight. The culture medium was then replaced with fresh medium containing cisplatin at 2 concentrations ( 1 or $2 \mu \mathrm{M})$, and the cells were incubated with cisplatin at $37^{\circ} \mathrm{C}$ for $48 \mathrm{~h}$. Immediately after the 48 -h incubation, the medium containing cisplatin was removed, and the cells were washed with PBS once. Subsequently, $25 \mu 1$ of AuNRs in PBS at the concentration of 2.5 or $5 \mathrm{nM}$ were added to the cisplatin-treated cells and exposed to $4 \mathrm{~min}$ of $808 \mathrm{~nm}$ wavelength NIR irradiation at $1.875 \mathrm{~W} / \mathrm{cm}^{2}$. As described above, the final percentage of cell death induced by the Cis + LANT combination treatment was evaluated using the PrestoBlue Assay immediately following LANT treatment. Each treatment combination was performed in quadruplicate $(n=4)$, and the results are expressed as the means \pm standard deviation.

Calculations for EC50 and Cisplatin dose reduction. The half-effective concentrations (EC50) of cisplatin and LANT for the 3 HNSCC cell lines were calculated with the IC50 calculator provided by AAT Bioquest ${ }^{\circledR}$ according to the Four-Parameter Logistic (4PL) model equation (Equation 1) describing the sigmoid-shaped response pattern as shown in Fig. 1 (35):

$$
y(x)=D+\frac{(A-D)}{1+\left(\frac{x}{c}\right)^{B}}
$$

(Equation 1)

where $\mathrm{y}(\mathrm{x})$ is the percentage of cell death induced by the treatment that corresponds to each ' $\mathrm{x}$ '; ' $\mathrm{x}$ ' is the concentration of the treatment used to establish the dose-response curve in logarithmic form; ' $\mathrm{A}$ ' is the highest percentage of cell death on the dose-response curve $\left(\mathrm{y}_{\max }\right)$; ' $\mathrm{B}$ ' is the hill slope of the dose-response curve; ' $\mathrm{C}$ ' is the $\mathrm{x}$-value (concentration) corresponding to the midway between ' $A$ ' and ' $D$ ' on the dose-response curve (i.e., the EC50 value); and ' $\mathrm{D}$ ' is the lowest percentage of cell death on the dose-response curve $\left(\mathrm{y}_{\min }\right)$ (Fig. 2).

To describe the synergistic therapeutic efficacy, the 4PL model equation was used to estimate the decrease in the cisplatin dose, comparing the combination treatment to the monotreatment. As LANT is not a drug, the combination index (CI) and other traditional methods for calculating the synergistic effects of a combination therapy did not apply to this study. Thus, calculating the dose reduction required an evaluation of the difference in doses at the same percentage of cell death: the percentage of cell death induced by the Cis + LANT combination treatment $\left(y^{\prime}\right)$ was evaluated at the same percentage of cell death caused by the cisplatin monotreatment (y) (i.e., $\left.y=y^{\prime}\right)$. Using the 4PL equation, the concentration of cisplatin monotreatment $(\mathrm{x})$ that would be required to induce the percentage of cell death $(\mathrm{y})$ equivalent to $\mathrm{y}^{\prime}$ (the percentage of cell death induced by the Cis + LANT combination treatment) was determined. The 4PL equation was also used to determine the dose reduction LANT introduced to cisplatin.

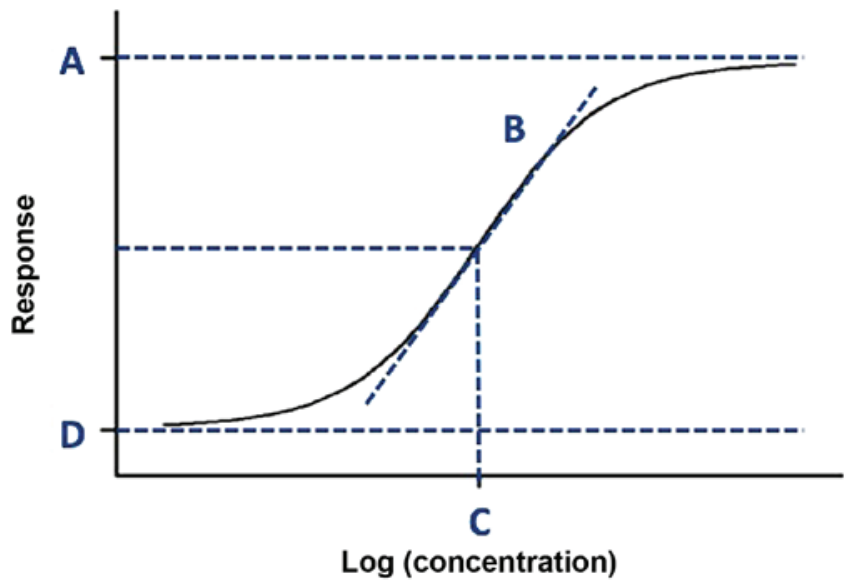

Figure 1. A sigmoidal-shaped dose-response curve corresponding to the Four-Parameter Logistic (4PL) model equation. The 4PL equation (see Equation 1) determined i) the half-effective concentrations (EC50) of cisplatin and LANT; ii) the concentration of cisplatin monotreatment (x) that would be required to induce the percentage of cell death (y) equivalent to $\mathrm{y}^{\prime}$ (the percentage of cell death induced by the Cis + LANT combination treatment); and iii) the dose reduction LANT introduced to cisplatin. Corresponding to the 4PL equation, 'A' is the highest percentage of cell death on the dose-response curve $\left(\mathrm{y}_{\max }\right)$; ' $\mathrm{B}$ ' is the hill slope of the dose-response curve; ' $\mathrm{C}$ ' is the $\mathrm{x}$-value (concentration) corresponding to the midway between 'A' and ' $D$ ' on the dose-response curve (i.e., the EC50 value); and ' $\mathrm{D}$ ' is the lowest percentage of cell death on the dose-response curve $\left(\mathrm{y}_{\min }\right)$.

Cisplatin monotreatment dose reduction calculation. Equation 1 above was used to calculate the percentage of cell death induced by each $\mathrm{Cis}$ monotreatment concentration corresponding to each concentration of Cis monotreatment used to establish the dose-response curve for the $3 \mathrm{HNSCC}$ cell lines. The measured and calculated values for A, B, C and D were inserted for the Detroit 562, FaDu and CAL27 cells, according to Equations 1a, $1 \mathrm{~b}$ and 1c, respectively:

For Detroit 562 cells,

$$
y=0.896+\frac{(109.024-0.896)}{1+\left(\frac{x}{9.330}\right)^{-1.414}}
$$

(Equation 1a)

For FaDu cells,

$$
\boldsymbol{y}=-0.054+\frac{(117.085+0.054)}{1+\left(\frac{x}{5.678}\right)^{-0.750}}
$$

(Equation 1b)

For CAL 27 cells,

$$
\boldsymbol{y}=-0.445+\frac{(98.510+0.445)}{1+\left(\frac{x}{4.053}\right)^{-1.416}}
$$

(Equation 1c)

Cis + LANT combination treatment dose comparison. Equation 2 was used to calculate the percentage of cell death induced by the combination, Cis + LANT treatment, that corresponds to each concentration of Cis used to establish the dose-response curve.

For Cis + PNT combination treatment,

$$
y^{\prime}\left(x^{\prime}\right)=D+\frac{(A-D)}{1+\left(\frac{x \prime}{C}\right)^{B}}
$$

(Equation 2)

where $y^{\prime}\left(x^{\prime}\right)$ is the percentage of cell death induced by the combination Cis + LANT treatment that corresponds to each ' $x$ '; ' $x$ ' is the concentration of the combination $\mathrm{Cis}+$ LANT treatment used to establish the dose-response curve in 

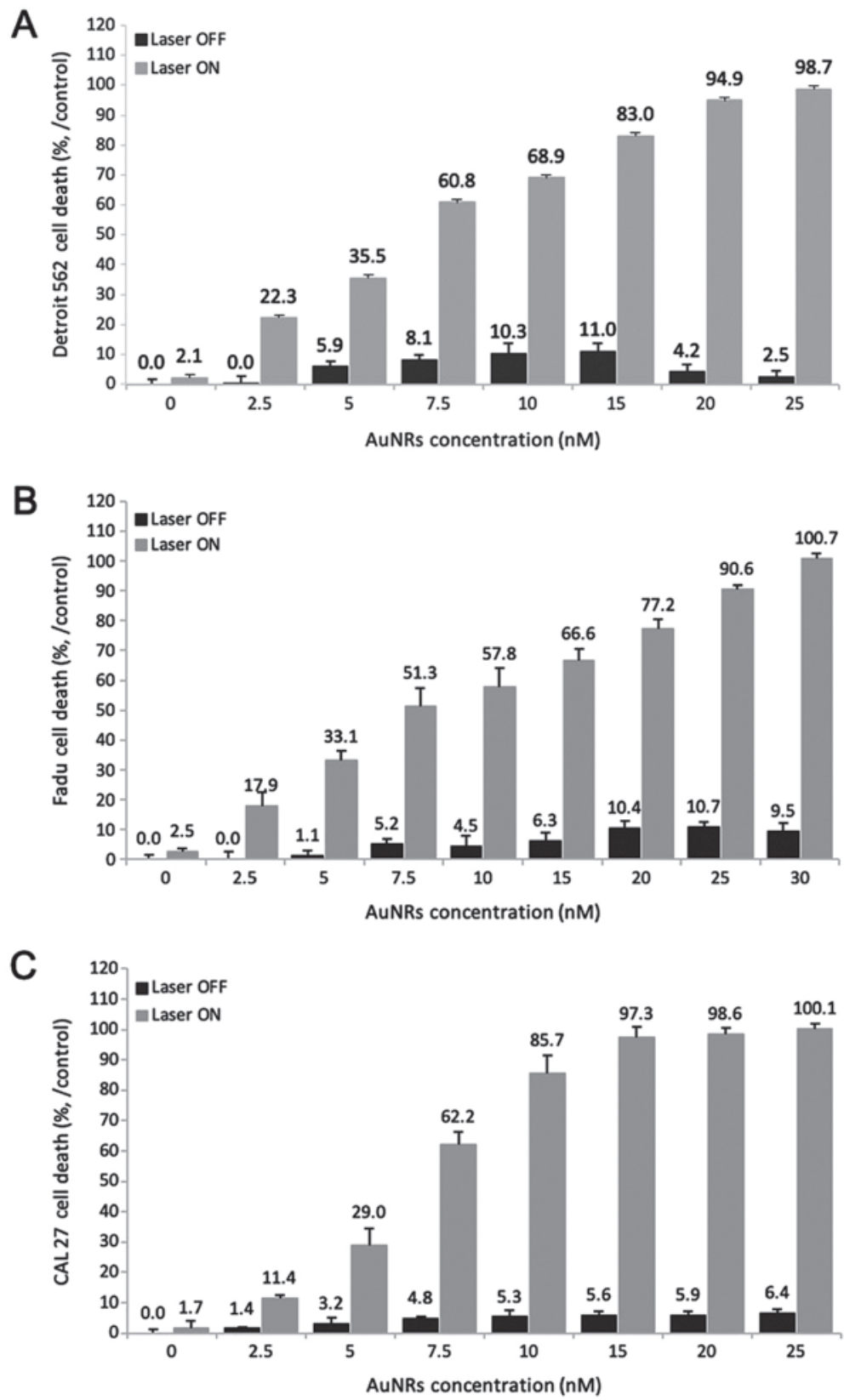

Figure 2. LANT monotreatment dose responses for HNSCC cell lines. Mean percentage of cell death induced by LANT monotreatment for (A) Detroit 562, (B) FaDu and (C) CAL 27 cells at concentrations of 0, 2.5, 5, 7.5, 10, 15, 20, 25 and $30 \mathrm{nM}$ with $25 \mu 1$ of AuNRs per well, without (Laser OFF) and with (Laser ON) $808 \mathrm{~nm}$ NIR activation for $4 \mathrm{~min}$ at $1.875 \mathrm{~W} / \mathrm{cm}^{2}$. Columns present the mean and the standard deviation of $\mathrm{n}=6$. AuNRs, gold nanorods; HNSCC, head and neck squamous cell carcinoma; LANT, Laser-Activated NanoTherapy; NIR, near-infrared.

logarithmic form; 'A' is the highest percentage of cell death on the dose-response curve $\left(\mathrm{y}_{\max }^{\prime}\right)$; ' $\mathrm{B}$ ' is the hill slope of the dose-response curve; ' $\mathrm{C}$ ' is the $\mathrm{x}$ '-value (concentration) corresponding to the midway between ' $\mathrm{A}$ ' and ' $\mathrm{D}$ ' on the dose-response curve (i.e., the EC50 value); and ' $D$ ' is the lowest percentage of cell death on the dose-response curve $\left(\mathrm{y}_{\text {min }}^{\prime}\right)$.

Considering that $y^{\prime}\left(x^{\prime}\right)$ in Equation 2 was derived from real data, $y^{\prime}\left(x^{\prime}\right)=y(x)$ from Equation 1, and the present study were only interested in the percentage of cell death that is in common with both Cis monotreatment and Cis + LANT combination treatment, the $y^{\prime}\left(x^{\prime}\right)$ from Equation 2 was substituted for $\mathrm{y}(\mathrm{x})$ in Equation 1 and solved for ' $\mathrm{x}$ ' to calculate the Cis monotreatment dose.
Therefore, the dose reduction realized by combining Cis with PNT was calculated according to Equation 3:

$$
\text { Dose reduction }(\%)=100 \times \frac{\left(x-x^{\prime}\right)}{x}
$$

(Equation 3)

Statistical analysis. To assess differences in cell death percentages across the 6 treatment conditions, a one-way Analysis of Variance (ANOVA) was performed with post hoc tests using the Bonferroni correction. The statistical significance was set at $\mathrm{P}<0.05$. Prior to the ANOVA estimation, statistical tests were performed for the assumptions of homogeneity of variance and normality using Bartlett's and Shapiro-Wilk tests, respectively. For these tests, $\mathrm{P}>0.05$ indicated that these assumptions were met. These procedures were repeated for 
Table I. EC50 values for LANT and cisplatin mono-treatments.

Cell line

\begin{tabular}{lcrc} 
EC50 & Detroit 562 & FaDu & CAL 27 \\
\hline LANT $(\mathrm{nM})$ & 8.08 & 11.03 & 6.68 \\
Cisplatin $(\mu \mathrm{M})$ & 9.33 & 5.05 & 4.05
\end{tabular}

LANT and Cisplatin monotreatment concentrations that resulted in the EC50 values for 3 HNSCC cell lines: Detroit 562, FaDu and CAL 27. EC50, half-effective concentrations; HNSCC, head and neck squamous cell carcinoma; LANT, Laser-Activated NanoTherapy.

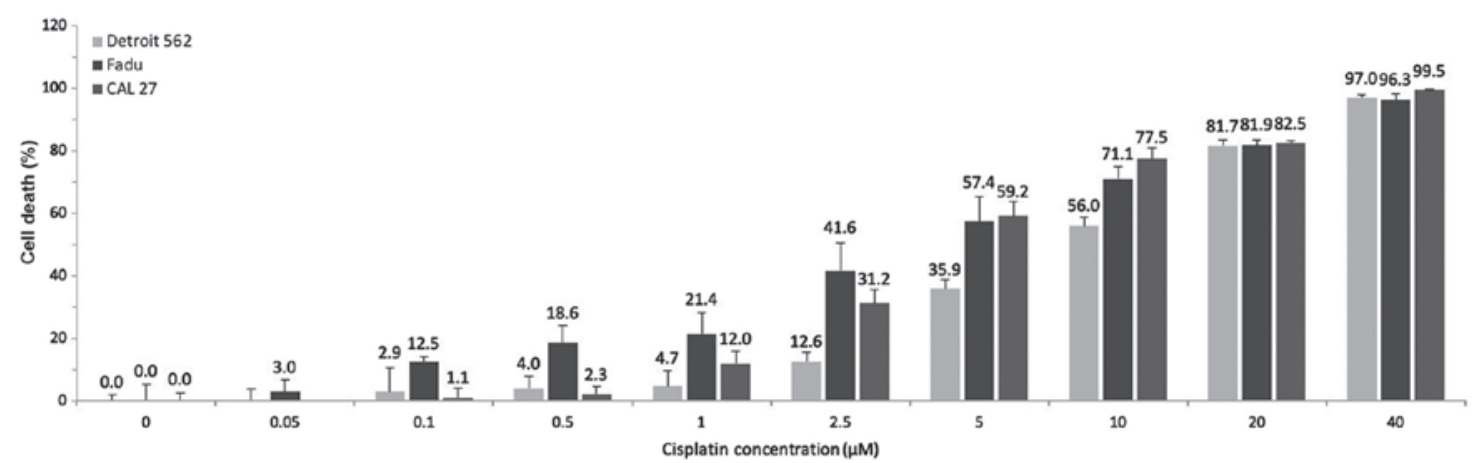

Figure 3. Cisplatin monotreatment dose responses for HNSCC cell lines. The mean percentage of cell death induced by a 48-h incubation with cisplatin as a monotreatment at 9 different concentrations, 0.05-40 $\mu \mathrm{M}$, for Detroit 562, FaDu and CAL 27 cells. Columns present the mean and the standard deviation of $\mathrm{n}=6$. HNSCC, head and neck squamous cell carcinoma.

each cell line, resulting in a total of 3 sets of analyses. The comparisons of interest for the present study are those between cisplatin alone treatments (i.e., $1 \mu \mathrm{M} \mathrm{Cis} \mathrm{and} 2 \mu \mathrm{M} \mathrm{Cis})$ and the treatments involving a combination of the cisplatin and LANT (i.e., $1 \mu \mathrm{M}$ Cis $+2.5 \mathrm{nM}$ LANT; $1 \mu \mathrm{M}$ Cis $+5 \mathrm{nM}$ LANT; $2 \mu \mathrm{M}$ Cis $+2.5 \mathrm{nM}$ LANT; and $2 \mu \mathrm{M}$ Cis $+5 \mathrm{nM}$ LANT). All analyses were performed using $\mathrm{R}$ statistical software (R Core Team, 2019).

\section{Results}

Effects of LANT monotreatment. The therapeutic efficacy, dose-response curves and half effective concentration (EC50) were established in vitro for LANT as a monotherapy for HNSCC. To determine the percentage of cell death induced by AuNRs alone (Laser OFF) compared to LANT (Laser ON), an $808 \mathrm{~nm}$ NIR laser, for $4 \mathrm{~min}$ at $1.875 \mathrm{~W} / \mathrm{cm}^{2}$, was used to excite the AuNRs at 8 or 9 concentrations: 0, 2.5, 5, 7.5, 10, 15, 20, 25 and $30 \mathrm{nM}$. Fig. 2 illustrates the concentration-dependent cell death induced by LANT monotherapy for 3 HNSCC cell lines, Detroit 562 (Fig. 2A), FaDu (Fig. 2B) and CAL 27 (Fig. 2C). Under the conditions in this study, LANT induced substantial death in all cell lines compared to the AuNRs alone (Laser OFF). Increasing the AuNR concentration in LANT directly increased the percentage of cell death. Furthermore, the CAL 27 cells were the least sensitive to LANT at the lower AuNR concentrations (2.5 and $5 \mathrm{nM}$ ) compared to the Detroit 562 and FaDu cells under the same conditions. However, the CAL 27 cells were the most sensitive to LANT at the higher AuNR concentrations used for LANT
$(7.5,10,15,20$ and $25 \mathrm{nM})$ compared to the Detroit 562 and $\mathrm{FaDu}$ cells under the same conditions.

The FaDu cells required a higher EC50 value of LANT than the Detroit 562 and CAL 27 cells: the EC50 values of LANT for treating the Detroit 562, FaDu and CAL 27 cells were 8.08, 11.03 and $6.68 \mathrm{nM}$, respectively (Table I). Furthermore, the FaDu cells required an additional treatment condition, at $30 \mathrm{nM}$, to achieve the approximately $100 \%$ cell death obtained in the other cell lines at $25 \mathrm{nM}$ (Fig. 2). Consistent with previous findings (34), LANT induced $\sim 100 \%$ cell death in all 3 HNSCC cell lines at $25 \mathrm{nM}$ and higher doses.

Effects of cisplatin monotreatment. To establish the dose-response curves and EC50 for cisplatin as a monotherapy for the treatment of the HNSCC cell lines, Detroit 562, FaDu and CAL 27, the percentage of cell death induced was determined after incubating the cells with cisplatin for $48 \mathrm{~h}$ at 9 different concentrations ranging from $0.05-40 \mu \mathrm{M}$. The concentration-dependent cell death induced by cisplatin monotherapy is illustrated in Fig. 3.

Increasing the cisplatin concentration was directly proportional to the increase in the percentage of cell death. However, administering the high cisplatin doses in humans necessary to achieve a complete therapeutic response after $48 \mathrm{~h}$ would result in patient intolerance due to increased severe side-effects and toxicity. The FaDu cells were more sensitive to cisplatin at doses $\leq 2.5 \mu \mathrm{M}$ than the Detroit 562 and CAL 27 cells, whereas all 3 cell lines were equally responsive to cisplatin at doses $\geq 20 \mu \mathrm{M}$. The EC50 values of cisplatin for treating the Detroit 562, FaDu, and CAL 27 cells were 9.33, 5.05 and $4.05 \mu \mathrm{M}$, 
Table II. Descriptive statistics for cisplatin monotreatment and Cis + LANT combination treatment outcomes.

\begin{tabular}{|c|c|c|c|c|c|c|c|}
\hline \multirow[b]{2}{*}{ Cell line } & \multirow[b]{2}{*}{ Statistic } & \multicolumn{6}{|c|}{ Treatment } \\
\hline & & $1 \mu \mathrm{M}$ Cis & $\begin{array}{c}1 \mu \mathrm{M} \text { Cis }+ \\
2.5 \mathrm{nM} \text { LANT }\end{array}$ & $\begin{array}{c}1 \mu \mathrm{M} \mathrm{Cis}+ \\
5 \mathrm{nM} \mathrm{LANT}\end{array}$ & $2 \mu \mathrm{M} \mathrm{Cis}$ & $\begin{array}{c}2 \mu \mathrm{M} \text { Cis }+ \\
2.5 \mathrm{nM} \text { LANT }\end{array}$ & $\begin{array}{c}2 \mu \mathrm{M} \text { Cis }+ \\
5 \mathrm{nM} \text { LANT }\end{array}$ \\
\hline \multirow[t]{3}{*}{ Detroit 562} & Mean & 7.04 & 26.22 & 37.73 & 20.15 & 33.48 & 44.86 \\
\hline & $\mathrm{SD}$ & 3.64 & 1.74 & 2.68 & 2.09 & 2.59 & 2.03 \\
\hline & Obs & 4 & 4 & 4 & 4 & 4 & 4 \\
\hline \multirow[t]{3}{*}{$\mathrm{FaDu}$} & Mean & 21.64 & 39.44 & 51.73 & 33.62 & 53.67 & 59.77 \\
\hline & $\mathrm{SD}$ & 2.40 & 2.93 & 3.84 & 1.90 & 0.99 & 1.87 \\
\hline & Obs & 4 & 4 & 4 & 4 & 4 & 4 \\
\hline \multirow[t]{3}{*}{ CAL27 } & Mean & 11.18 & 34.99 & 58.48 & 23.40 & 38.39 & 75.46 \\
\hline & $\mathrm{SD}$ & 2.15 & 3.58 & 5.50 & 2.22 & 0.97 & 3.91 \\
\hline & Obs & 4 & 4 & 4 & 4 & 4 & 4 \\
\hline
\end{tabular}

Mean percentage (Mean) and standard deviation (SD) of cell death of 4 observations (Obs) induced for 6 treatment groups for the 3 cell lines, Detroit 562, FaDu and CAL 27. Cis, cisplatin; LANT, Laser-Activated NanoTherapy.

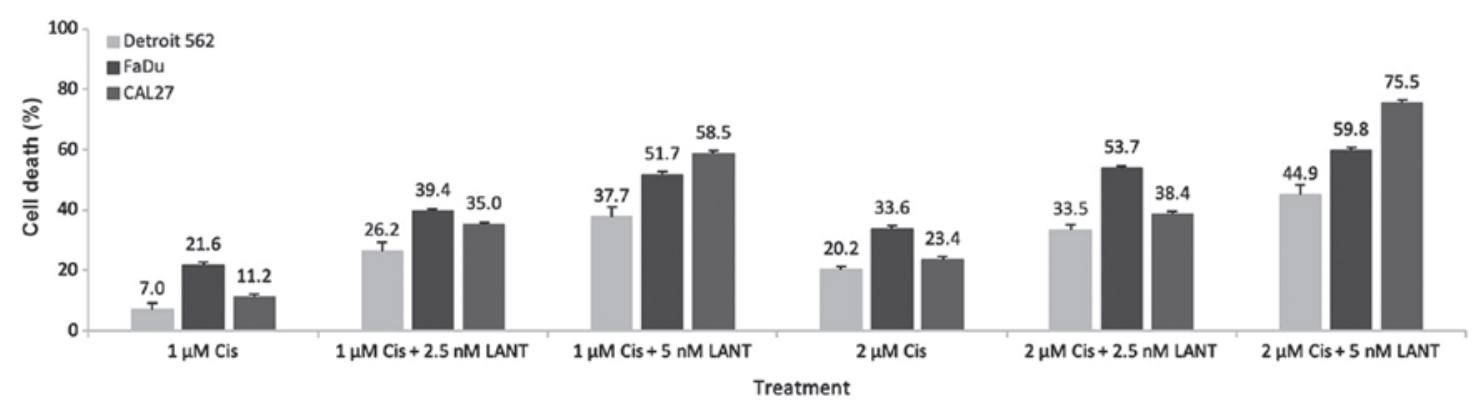

Figure 4. LANT and cisplatin combination treatment for HNSCC cell lines. The mean percentage of cell death induced by combining low dose cisplatin and low dose LANT was significantly higher than that by the same low dose of cisplatin monotreatment for Detroit 562 , FaDu and CAL 27 cells (corresponding to Tables II and III). The cisplatin concentrations of 1 and $2 \mu \mathrm{M}$ used in the combination treatments were less than half of the lowest cisplatin monotreatment EC50 values for all cell lines. Likewise, the AuNR concentration for LANT of 2.5 and 5 nM were also less than the lowest EC50 values from the LANT monotreatment. Cells were subjected to a 48 -h incubation with cisplatin at a concentration of 1 or $2 \mu \mathrm{M}$, as a monotreatment or combined with LANT at a concentration of 2.5 or $5 \mathrm{nM}$ using NIR excitation for $4 \mathrm{~min}$ at $1.875 \mathrm{~W} / \mathrm{cm}^{2}$. Columns present the mean and the standard deviation of $\mathrm{n}=4$. AuNRs, gold nanorods; HNSCC, head and neck squamous cell carcinoma; LANT, Laser-Activated NanoTherapy; NIR, near-infrared.

respectively (Table I). In the present study, $40 \mu \mathrm{M}$ of cisplatin resulted in approximately $100 \%$ cell death in all 3 cell lines during the 48-h treatment window.

Combination of cisplatin and LANT treatments. The monotreatment EC50 values that induced $50 \%$ cell death (Table I) informed the dose selection for the combination experiments to specifically narrow the focus to low doses for both cisplatin and LANT. To delineate and emphasize the efficacy of the Cis + LANT combination treatment, 1 and $2 \mu \mathrm{M}$ of cisplatin were used in the combination treatment as they were less than half of the concentration of the lowest cisplatin monotreatment EC50 values for all cell lines $(4.05 \mu \mathrm{M})$. Likewise, 2.5 and $5 \mathrm{nM}$ of AuNRs for LANT were selected as they were also less than half of the lowest EC50 values from the LANT monotreatment $(6.68 \mathrm{nM})$. The percentage of cell death due to the 4 Cis + LANT combination treatments, (cisplatin at 1 or $2 \mu \mathrm{M})+($ LANT at 2.5 or $5 \mathrm{nM})$, was significantly higher than that due to the 2 cisplatin monotreatments ( 1 or $2 \mu \mathrm{M})$ for all 3 cell lines (Fig. 4).
Descriptive statistics, ANOVA and post hoc tests. Based on the cell death percentage data shown in Fig. 4, the descriptive statistics, mean percentage (Mean), and standard deviation (SD) were summarized for the 6 treatment groups and 3 cell lines in Table II. The ANOVA test compared the means of the 6 treatment groups for 3 cell lines. There was a statistically significant difference in the means of most groups for all 3 cell lines. ANOVA and post hoc test outcomes were similar across all 3 cell types and the results are summarized in Table III. The post hoc analyses results for all 3 cell lines indicated statistically significant differences $(\mathrm{P}<0.05)$ in the majority of comparisons of interest between the 6 treatment groups.

Overall, the combination of treatments was significantly more effective than the corresponding cisplatin monotreatment. Specifically, the combinations $(1 \mu \mathrm{M}$ Cis $+2.5 \mathrm{nM}$ LANT; $1 \mu \mathrm{M}$ Cis $+5 \mathrm{nM}$ LANT; $2 \mu \mathrm{M}$ Cis $+2.5 \mathrm{nM}$ LANT; and $2 \mu \mathrm{M}$ Cis $+5 \mathrm{nM}$ LANT) were more effective at inducing death in all 3 cell lines than the corresponding cisplatin monotreatment ( $1 \mu \mathrm{M}$ Cis or $2 \mu \mathrm{M}$ Cis). There were 2 (of 15) 
Table III. Treatment group comparison.

\begin{tabular}{|c|c|c|c|c|c|c|c|}
\hline & & \multicolumn{2}{|c|}{ Detroit 562} & \multicolumn{2}{|c|}{$\mathrm{FaDu}$} & \multicolumn{2}{|c|}{ CAL 27} \\
\hline \multicolumn{2}{|c|}{ First column vs. second column } & $\begin{array}{c}\text { Mean } \\
\text { Diff }\end{array}$ & P-value & $\begin{array}{c}\text { Mean } \\
\text { Diff }\end{array}$ & P-value & $\begin{array}{c}\text { Mean } \\
\text { Diff }\end{array}$ & P-value \\
\hline $1 \mu \mathrm{M}$ Cis $+2.5 \mathrm{nM}$ LANT & $1 \mu \mathrm{M}$ Cis & 19.18 & $<0.0001^{\mathrm{a}}$ & 17.79 & $<0.0001^{\mathrm{a}}$ & 23.81 & $<0.0001^{\mathrm{a}}$ \\
\hline $1 \mu \mathrm{M}$ Cis $+5 \mathrm{nM}$ LANT & & 30.69 & $<0.0001^{\mathrm{a}}$ & 30.08 & $<0.0001^{\mathrm{a}}$ & 47.30 & $<0.0001^{\mathrm{a}}$ \\
\hline $2 \mu \mathrm{M}$ Cis $+2.5 \mathrm{nM}$ LANT & & 26.44 & $<0.0001^{\mathrm{a}}$ & 32.02 & $<0.0001^{\mathrm{a}}$ & 27.21 & $<0.0001^{\mathrm{a}}$ \\
\hline $2 \mu \mathrm{M}$ Cis $+5 \mathrm{nM}$ LANT & & 37.82 & $<0.0001^{\mathrm{a}}$ & 38.13 & $<0.0001^{\mathrm{a}}$ & 64.28 & $<0.0001^{\mathrm{a}}$ \\
\hline $1 \mu \mathrm{M}$ Cis $+2.5 \mathrm{nM}$ LANT & $2 \mu \mathrm{M} \mathrm{Cis}$ & 6.07 & $0.050^{\mathrm{b}}$ & 5.82 & $0.059^{\mathrm{b}}$ & 11.59 & $0.002^{\mathrm{a}}$ \\
\hline $1 \mu \mathrm{M}$ Cis $+5 \mathrm{nM}$ LANT & & 17.58 & $<0.0001^{\mathrm{a}}$ & 18.11 & $<0.0001^{\mathrm{a}}$ & 35.08 & $<0.0001^{\mathrm{a}}$ \\
\hline $2 \mu \mathrm{M}$ Cis $+2.5 \mathrm{nM}$ LANT & & 13.33 & $<0.0001^{\mathrm{a}}$ & 20.05 & $<0.0001^{\mathrm{a}}$ & 14.99 & $<0.0001^{\mathrm{a}}$ \\
\hline $2 \mu \mathrm{M}$ Cis $+5 \mathrm{nM}$ LANT & & 24.71 & $<0.0001^{\mathrm{a}}$ & 26.16 & $<0.0001^{\mathrm{a}}$ & 52.06 & $<0.0001^{\mathrm{a}}$ \\
\hline $2 \mu \mathrm{M}$ Cis & $1 \mu \mathrm{M} \mathrm{Cis}$ & 13.11 & $<0.0001^{\mathrm{a}}$ & 11.97 & $<0.0001^{\mathrm{a}}$ & 12.22 & $0.001^{\mathrm{a}}$ \\
\hline $1 \mu \mathrm{M}$ Cis $+5 \mathrm{nM}$ LANT & $1 \mu \mathrm{M}$ Cis $+2.5 \mathrm{nM}$ LANT & 11.51 & $<0.0001^{\mathrm{a}}$ & 12.29 & $<0.0001^{\mathrm{a}}$ & 23.49 & $<0.0001^{\mathrm{a}}$ \\
\hline $2 \mu \mathrm{M}$ Cis $+2.5 \mathrm{nM}$ LANT & & 7.26 & $0.012^{\mathrm{a}}$ & 14.23 & $<0.0001^{\mathrm{a}}$ & 3.40 & $>0.999$ \\
\hline $2 \mu \mathrm{M}$ Cis $+5 \mathrm{nM}$ LANT & & 18.64 & $<0.0001^{\mathrm{a}}$ & 20.34 & $<0.0001^{\mathrm{a}}$ & 40.47 & $<0.0001^{\mathrm{a}}$ \\
\hline $1 \mu \mathrm{M}$ Cis $+5 \mathrm{nM}$ LANT & $2 \mu \mathrm{M}$ Cis $+2.5 \mathrm{nM}$ LANT & 4.25 & 0.440 & -1.94 & $>0.999$ & 20.09 & $<0.0001^{\mathrm{a}}$ \\
\hline $2 \mu \mathrm{M}$ Cis $+5 \mathrm{nM}$ LANT & & 11.38 & $<0.0001^{\mathrm{a}}$ & 6.11 & $0.041^{\mathrm{a}}$ & 37.07 & $<0.0001^{\mathrm{a}}$ \\
\hline $2 \mu \mathrm{M}$ Cis $+5 \mathrm{nM}$ LANT & $1 \mu \mathrm{M}$ Cis $+5 \mathrm{nM}$ LANT & 7.13 & $0.014^{\mathrm{a}}$ & 8.05 & $0.004^{\mathrm{a}}$ & 16.98 & $<0.0001^{\mathrm{a}}$ \\
\hline
\end{tabular}

A one-way analysis of variance (ANOVA) with post hoc tests using the Bonferroni correction illustrates the differences in cell death percentages across the 6 treatment conditions for Detroit 562, FaDu and CAL 27 cell lines comparing the efficacy of cisplatin monotreatment and combination treatment groups. The results show post hoc tests with Bonferroni correction. Prior to the ANOVA estimation, statistical tests were performed for the assumptions of homogeneity of variance and normality using Bartlett's and Shapiro-Wilk tests, respectively. For these tests, $\mathrm{P}>0.05$ indicated that these assumptions were met. The statistical significance was set at $\mathrm{P}<0.05$. For the treatment group comparison, the first column is more effective than the second column by the mean difference amount; ${ }^{a} \mathrm{P}<0.05$; ${ }^{\mathrm{b}} \mathrm{P}<0.10$; Mean Diff, mean difference; Cis, cisplatin; LANT, Laser-Activated NanoTherapy.

Table IV. Reducing effect on cisplatin dose by Cisplatin + LANT combination treatments.

Treatment combination

\begin{tabular}{|c|c|c|c|c|c|}
\hline \multirow[b]{2}{*}{ Cell line } & \multirow[b]{2}{*}{ Outcome } & \\
\hline & & $\begin{array}{c}1 \mu \mathrm{M} \text { Cis }+ \\
2.5 \mathrm{nM} \mathrm{LANT}\end{array}$ & $\begin{array}{c}1 \mu \mathrm{M} \mathrm{Cis}+ \\
5 \mathrm{nM} \mathrm{LANT}\end{array}$ & $\begin{array}{c}2 \mu \mathrm{M} \mathrm{Cis}+ \\
2.5 \mathrm{nM} \mathrm{LANT}\end{array}$ & $\begin{array}{l}2 \mu \mathrm{M} \text { Cis }+ \\
5 \mathrm{nM} \text { LANT }\end{array}$ \\
\hline \multirow[t]{3}{*}{ Detroit 562} & Cell death $(\%)$ in combo & 26.2 & 37.7 & 33.5 & 44.9 \\
\hline & $\begin{array}{l}\text { Est. conc. }(\mu \mathrm{M}) \text { of Cis mono } \\
\text { to obtain the same } \% \text { cell death }\end{array}$ & 4.0 & 5.9 & 5.2 & 7.1 \\
\hline & Cis dose reduction $(\%)$ & 75.2 & 82.9 & 61.2 & 72.0 \\
\hline \multirow[t]{3}{*}{$\mathrm{FaDu}$} & Cell death $(\%)$ in combo & 39.4 & 51.7 & 53.7 & 59.8 \\
\hline & $\begin{array}{l}\text { Est. conc. }(\mu \mathrm{M}) \text { of Cis mono } \\
\text { to obtain the same } \% \text { cell death }\end{array}$ & 2.3 & 4.2 & 4.6 & 6.0 \\
\hline & Cis dose reduction $(\%)$ & 56.6 & 76.0 & 56.1 & 66.7 \\
\hline \multirow[t]{3}{*}{ CAL 27} & Cell death $(\%)$ in combo & 35.0 & 58.5 & 38.4 & 75.5 \\
\hline & $\begin{array}{l}\text { Est. conc. }(\mu \mathrm{M}) \text { of Cis mono } \\
\text { to obtain the same } \% \text { cell death }\end{array}$ & 2.7 & 5.3 & 3.0 & 9.4 \\
\hline & Cis dose reduction $(\%)$ & 62.7 & 81.2 & 32.8 & 78.7 \\
\hline
\end{tabular}

An outline, per HNSCC cell line, of the percentage of cisplatin dose reduction, based on the concentration of the cisplatin monotreatment that is needed to achieve the same percentage of cell death as the concentration of cisplatin used in the Cis + LANT combination treatment. Bold font indicates that the $1 \mu \mathrm{M}$ Cis $+5 \mathrm{nM}$ LANT combination resulted in the highest percentage of cisplatin dose reduction. AuNRs, gold nanorods; Conc., concentration; Cis, cisplatin; LANT, Laser-Activated NanoTherapy. 
comparisons that did not exhibit statistically significant differences in their efficacy: $1 \mu \mathrm{M}$ Cis $+5 \mathrm{nM}$ LANT vs. $2 \mu \mathrm{M}$ Cis $+2.5 \mathrm{nM}$ LANT for Detroit 562 and FaDu cell lines; and $2 \mu \mathrm{M}$ Cis + $2.5 \mathrm{nM}$ LANT vs. $1 \mu \mathrm{M}$ Cis $+2.5 \mathrm{nM}$ LANT for CAL 27 cells, implying that these treatments were equivalent.

The most effective combination with the most notable increase in cell death over its corresponding cisplatin monotreatment was $1 \mu \mathrm{M}$ Cis $+5 \mathrm{nM}$ LANT, with approximately 2- to 5-fold greater cell death than $1 \mu \mathrm{M}$ cisplatin monotreatment. The lowest therapeutic efficacy improvement was observed with the $2 \mu \mathrm{M}$ Cis $+2.5 \mathrm{nM}$ LANT combination, with $<2$-fold more cell death than the $2 \mu \mathrm{M}$ Cis monotreatment.

The 4PL model equation was used to determine the synergistic therapeutic efficacy of the combination treatment and the percentage of cisplatin dose reduction (35). The cell death percentages induced by the 4 combinations of Cis + LANT ( 1 or $2 \mu \mathrm{M}$ Cis +2.5 or $5 \mathrm{nM}$ LANT) were evaluated. The dose of cisplatin necessary to achieve the same cell death percentage as the corresponding cisplatin used in the combination treatments was determined. The reduction in dose was derived using cell death percentage as the commonality (Table IV).

The $1 \mu \mathrm{M}$ Cis $+5 \mathrm{nM}$ LANT combination treatment resulted in the highest percentage of cisplatin dose reduction: 82.9, 76.0 and 81.2\% for the Detroit 562, FaDu and CAL 27 cell lines, respectively. For example, the $82.9 \%$ dose reduction for the Detroit 562 cells elucidates that $5.9 \mu \mathrm{M}$ Cis as a monotreatment is required to achieve the same $37.7 \%$ cell death as the $1 \mu \mathrm{M}$ Cis used in the $1 \mu \mathrm{M}$ Cis $+5 \mathrm{nM}$ LANT combination treatment.

\section{Discussion}

Adjuvant, neoadjuvant and combination therapies are an emerging and viable approach to overcome the current challenges experienced by patients who cannot receive or tolerate the standard of care chemotherapeutic treatment regimens. This patient-centered solution reduces the standard drug dosage administered, thereby reducing toxicity, side-effects and poor prognosis. Cisplatin, a standard chemotherapeutic therapy for HNSCC, has shown promise to decrease toxicity and side-effects at lower doses when combined with other therapeutic interventions. Several emerging clinical studies have combined cisplatin with other interventions and demonstrated dose reduction while maintaining efficacy. A previous study compared cisplatin combined with paclitaxel to high-dose cisplatin in patients with locally advanced HNSCC receiving concurrent radiation. That study demonstrated less acute and chronic toxicities at one-fifth of the cisplatin dose with comparable overall survival rates and efficacy (10). In another study that followed patients with locally advanced HNSCC, induction chemotherapy combining docetaxel, cisplatin, and fluorouracil (TPF), in comparison to cisplatin and fluorouracil (PF), demonstrated significant improvement in overall-, median- and progression-free survival without increasing treatment-related toxicity, as measured by tracheostomies and dependence on gastric feeding tubes (18).

Pre-clinical studies are beginning to emerge and show promise for cisplatin dose reduction and enhanced drug delivery by combining cisplatin with various unconventional interventions, such as nanomedicines and therapeutic nanotechnologies (28). One such example is a nano-enabled version of cisplatin combined with a nano-enabled version of rapamycin. Rapamycin, which inhibits angiogenesis and proliferation through the mTOR pathway, has been shown to enhance human melanoma cell sensitivity to cisplatin, induce significant apoptosis in vitro, inhibit the growth of a xenografted tumor and permit the enhanced tumor penetration of NPs in vivo (36). Another example is a theranostic nanomedicine study of gold nanoclusters conjugated to folic acid and cisplatin that significantly improved the efficacy of cisplatin by accelerating the cellular uptake and increasing cytotoxicity in breast cancer cells. These conjugates also inhibited growth and lung metastasis of orthotopically implanted breast tumors (37).

There is a class of nanoparticle drug delivery systems (DDSs) used to facilitate the delivery of cisplatin, relying on the enhanced permeability and retention (EPR) effect (28). These include organic (polymeric NPs, polymeric micelles, polymeric conjugates, dendrimers, liposomes, polymer-coated liposomes, and nanocapsules), inorganic (carbon nanotubes, iron oxide NPs, gold NPs, and mesoporous silica NPs) and hybrid NPs (nanoscale coordination polymers and polysilsesquioxane NPs) (28).

Another class of nanotechnologies that may enhance drug performance, aside from the class of previously mentioned nanomedicines, are the less explored, therapeutic metallic nanoparticles. A previous study demonstrated that zinc oxide nanoparticles (ZnO-NPs) induced tumor-selective cell death in HNSCC in vitro and enhanced cytotoxic effects when irradiated with UVA-1 in combination with cisplatin and paclitaxel. Although UVA-1 activated ZnO-NPs alone produced a significant decrease in viable cells, this effect was further enhanced when combined with cisplatin and paclitaxel, indicating a synergistic association between the photocatalytic nanoparticles and the chemotherapeutic drug combination $(38,39)$.

Previous LANT research by the authors, also in this class of therapeutic metallic nanoparticles, used AuNRs to demonstrate approximately $100 \%$ cell death in vitro and complete xenografted tumor regression in vivo in $\mathrm{HNSCC}$ when exposed to a specific excitation wavelength of near-infrared laser light (785 nm) (34). In the present study, LANT, combined with cisplatin as an adjuvant therapy, improved the therapeutic efficacy of cisplatin by $>5$-fold that of cisplatin monotreatment and reduced the effective cisplatin dose in 3 HNSCC cell lines. This cisplatin + LANT combination therapy is designed to lower the effective dose, decrease treatment times and minimize the side-effects of cisplatin monotreatment. This nano-drug adjuvant therapy approach may also circumvent systemic delivery and the need for conjugation by overriding the tumor microenvironment and avoiding the delivery obstacles encountered during uptake by the reticuloendothelial system. This strategy is based on effective intratumoral LANT delivery (34) and may hold promise of becoming an additional option for patients who cannot tolerate the full dose of the standard cisplatin regimen.

In conclusion, the present study demonstrates the potential of cisplatin and LANT co-therapy as a possible addition to the adjuvant therapy options for the treatment of HNSCC. The combination of cisplatin + LANT demonstrates up to 5.4-fold greater therapeutic efficacy than cisplatin monotreatment. The most effective treatment combination, $1 \mu \mathrm{M}$ Cis $+5 \mathrm{nM}$ LANT, demonstrates an $82.9 \%$ dose reduction in Detroit 562 
cells, compared to the $5.9 \mu \mathrm{M}$ of Cis monotreatment required to achieve the same $37.7 \%$ cell death in $48 \mathrm{~h}$. This observation suggests that a lower cisplatin dose may be used in combination with LANT to achieve the same therapeutic efficacy as higher doses of cisplatin monotreatment. Directly translating this in vitro concentration to an animal or human dose is not a process clearly outlined in the literature. However, if the same $82.9 \%$ dose reduction was applied to the standard human cisplatin dose schedule, LANT could reduce the standard clinical dose of cisplatin from $2.54 \mathrm{mg} / \mathrm{kg}\left(100 \mathrm{mg} / \mathrm{m}^{2}\right)$ every 3 to 4 weeks to $0.43 \mathrm{mg} / \mathrm{kg}\left(17.1 \mathrm{mg} / \mathrm{m}^{2}\right)$ in $48 \mathrm{~h}$. The combination of LANT and cisplatin suggests that LANT may boost the therapeutic effect of low doses of cisplatin, and may result in fewer side-effects for cancer patients and improved patient outcomes. It also suggests that adding LANT to the current standard cisplatin dose schedule may provide a more aggressive treatment option if desired; however, this requires additional study.

It is suggested that these findings may be extended to a variety of other cancer types. It is also suggested that these findings may extend to the development of novel adjuvant therapy formulations, incorporating other metallic-based nanoparticle technologies, such as other gold, silver, platinum and iron nanoparticles. Other therapeutic nanotechnologies, such as dendrimers, polymers and liposomes may also serve as adjuvant, multi-step interventions that may be less expensive and more effective than the conjugated, hybrid versions of the same components. Consequently, future studies should also consider the improvement cisplatin may have to the other treatment component in the adjuvant therapy, including, but not limited to, LANT and other nanotechnologies. Future studies are also required to address the impact of the combination treatment on oral keratinocytes, fibroblasts, the mechanism of cell death and decreased cellular proliferation.

\section{Acknowledgements}

The authors would like to thank Dr Adejare Adeboye, University of the Sciences; Dr William E. Grizzle, University of Alabama at Birmingham; Dr James Lillard, Morehouse School of Medicine; Mr. Eric Spears, Ora Lee Smith Cancer Research Foundation; Miss Maya Cothran, Ora Lee Smith Cancer Research Foundation; and Dr Ed Childs, Morehouse School of Medicine for their support and encouragement during the preparation of this manuscript. The authors would also like to thank the supporters and volunteers at the Ora Lee Smith Cancer Research Foundation for their endeavors to translate LANT from bench to bedside, while making it affordable and accessible.

\section{Funding}

The study was supported by Award no. I01BX007080 from the Biomedical Laboratory Research and Development Service of the VA Office of Research and Development.

\section{Availability of data and materials}

All data generated or analyzed during this study are included in this published article.

\section{Authors' contributions}

All authors listed made substantial, direct, and intellectual contributions to the work discussed in this manuscript. HNG developed the LANT technology and protocols. HNG, GYL and JAM designed, drafted and revised the manuscript. GYL performed the experiments. JAM, KPS and SMP performed the statistical analysis. All authors analyzed the data, read and approved the final manuscript.

\section{Ethics approval and consent to participate}

Not applicable.

\section{Patient consent for publication}

Not applicable.

\section{Competing interests}

The authors declare that they have no competing interests.

\section{References}

1. Siegel R, Naishadham D and Jemal A: Cancer statistics, 2013. CA Cancer J Clin 63: 11-30, 2013.

2. Bray F, Ferlay J, Soerjomataram I, Siegel RL, Torre LA, Jemal A: Global cancer statistics 2018: GLOBOCAN estimates of incidence and mortality worldwide for 36 cancers in 185 countries. CA Cancer J Clin 68: 394-424, 2018.

3. Blanchard P, Baujat B, Holostenco V, Bourredjem A, Baey C, Bourhis J and Pignon JP; MACH-CH Collaborative group: Meta-analysis of chemotherapy in head and neck cancer (MACH-NC): A comprehensive analysis by tumour site. Radiother Oncol 100: 33-40, 2011.

4. Marur S and Forastiere AA: Head and neck squamous cell carcinoma: Update on epidemiology, diagnosis, and treatment. Mayo Clin Proc 91: 386-396, 2016.

5. Dauzier E, Lacas B, Blanchard P, Le QT, Simon C, Wolf G, Janot F, Horiuchi M, Tobias JS, Moon J, et al: Role of chemotherapy in 5000 patients with head and neck cancer treated by curative surgery: A subgroup analysis of the meta-analysis of chemotherapy in head and neck cancer. Oral Oncol 95: 106-114, 2019.

6. Alsahafi E, Begg K, Amelio I, Raulf N, Lucarelli P, Sauter T and Tavassoli M: Clinical update on head and neck cancer: Molecular biology and ongoing challenges. Cell Death Dis 10: 540, 2019.

7. Pendleton KP and Grandis JR: Cisplatin-based chemotherapy options for recurrent and/or metastatic squamous cell cancer of the head and neck. Clin Med Insights Ther 2013: 10.4137/CMT. S10409, 2013

8. Ghosh S: Cisplatin: The first metal based anticancer drug. Bioorg Chem 88: 102925, 2019.

9. Dasari S and Tchounwou PB: Cisplatin in cancer therapy: Molecular mechanisms of action. Eur J Pharmacol 740: 364-378, 2014.

10. Furqan M, Snyders TP, Saqlain MU, Mott SL, Laux D, Snow A, Anderson CM, Watkins JM and Clamon GH: Comparing high-dose cisplatin with cisplatin-based combination chemotherapy in definitive concurrent chemoradiation setting for locally advanced head and neck squamous cell carcinoma (LAHNSCC). Cancer Med 8: 2730-2739, 2019.

11. Florea AM and Büsselberg D: Cisplatin as an anti-tumor drug: Cellular mechanisms of activity, drug resistance and induced side effects. Cancers (Basel) 3: 1351-1371, 2011.

12. Towne TG and Murray A: Encyclopedia of Toxicology. 3rd edition). Academic Press, 2014.

13. Pratt WB and Ruddon RW: The anticancer drugs. Oxford University Press, 1979.

14. Makovec T: Cisplatin and beyond: Molecular mechanisms of action and drug resistance development in cancer chemotherapy. Radiol Oncol 53: 148-158, 2019. 
15. Yamano Y, Uzawa K, Saito K, Nakashima D, Kasamatsu A, Koike H, Kouzu Y, Shinozuka K, Nakatani K, Negoro K, et al: Identification of cisplatin-resistance related genes in head and neck squamous cell carcinoma. Int J Cancer 126: 437-449, 2010.

16. Marur S and Forastiere AA: Head and neck cancer: Changing epidemiology, diagnosis, and treatment. Mayo Clin Proc 83: 489-501, 2008.

17. American Cancer Society: Global cancer facts and figures 2018. Atlanta, American Cancer Society, 2018.

18. Cho H, Nishiike S, Yamamoto Y, Takenaka Y, Nakahara S, Yasui T, Hanamoto A and Inohara H: Docetaxel, Cisplatin, and fluorouracil for patients with inoperable recurrent or metastatic head and neck squamous cell carcinoma. Auris Nasus Larynx 42: 396-400, 2015

19. Lorch J, Goloubeva O, Haddad R, Cullen K, Sarlis N, Tishler R, Tan M, Fasciano J, Sammartino DE and Posner MR; TAX 324 Study Group: Induction chemotherapy with Cisplatin and fluorouracil alone or in combination with docetaxel in locally advanced squamous-cell cancer of the head and neck: Long-term results of the TAX 324 randomized phase 3 trial. Lancet Oncol 12: 153-159, 2011

20. Porceddu SV, Scotté F, Aapro M, Salmio S, Castro A Launay-Vacher V and Licitra L: treating patients with locally advanced squamous cell carcinoma of the head and neck unsuitable to receive cisplatin-based therapy. Front Oncol 9: 1522, 2020

21. Szturz P, Cristina V, Herrera Gómez RG, Bourhis J, Simon C and Vermorken JB: Cisplatin eligibility issues and alternative regimens in locoregionally advanced head and neck cancer: Recommendations for clinical practice. Front Oncol 9: 464, 2019.

22. Peng H, Chen L, Li WF, Guo R, Mao YP, Zhang Y, Zhang F, Liu LZ, Tian L,Lin AH, et al: The cumulative cisplatin dose affects the long-term survival outcomes of patients with nasopharyngeal carcinoma receiving concurrent chemoradiotherapy. Sci Rep 6 : $24332,2016$.

23. Le $X$ and Hanna EY: Optimal regimen of cisplatin in squamous cell carcinoma of head and neck yet to be determined. Ann Transl Med 6: 229, 2018

24. Strojan P, Vermorken JB, Beitler JJ, Saba NF, Haigentz M Jr, Bossi P, Worden FP, Langendijk JA, Eisbruch A, Mendenhall WM, et al: Cumulative cisplatin dose in concurrent chemoradiotherapy for head and neck cancer: A systematic review. Head Neck 38 (Suppl 1): E2151-E2158, 2016.

25. Szturz P, Wouters K, Kiyota N, Tahara M, Prabhash K, Noronha V, Adelstein D, Van Gestel D and Vermorken JB: Low-dose vs. High-dose cisplatin: Lessons learned from 59 chemoradiotherapy trials in head and neck cancer. Front Oncol 9: 86, 2019.

26. Mashhour K and Hashem W: Cisplatin weekly versus every 3 weeks concurrently with radiotherapy in the treatment of locally advanced head and neck squamous cell carcinomas: What is the best dosing and schedule? Asian Pac J Cancer Prev 21: 799-807, 2020.

27. Nouman M, Haider G, Bukhari N, Yousuf A, Nouman R, Shaikh MR, Hussain S, Pavan B, Rahool R, Memon P, et al: Response rate of cisplatin plus docetaxel as primary treatment in locally advanced head and neck carcinoma (squamous cell types). Asian Pac J Cancer Prev 21: 825-830, 2020.
28. Duan X, He C, Kron SJ and Lin W: Nanoparticle formulations of cisplatin for cancer therapy. Wiley Interdiscip Rev Nanomed Nanobiotechnol 8: 776-791, 2016.

29. Kayyali MN, Ramsey AJ, Higbee-Dempsey EM, Yan L, O'Malley BW Jr, Tsourkas A and Li D: The development of a nano-based approach to alleviate cisplatin-induced ototoxicity. J Assoc Res Otolaryngol 19: 123-132, 2018.

30. Mehtala JG, Torregrosa-Allen S, Elzey BD, Jeon M, Kim C and Wei A: Synergistic effects of cisplatin chemotherapy and gold nanorod-mediated hyperthermia on ovarian cancer cells and tumors. Nanomedicine (Lond) 9: 1939-1955, 2014.

31. Miao L, Guo S, Zhang J, Kim WY and Huang L: Nanoparticles with precise ratiometric co-loading and co-delivery of gemcitabine monophosphate and cisplatin for treatment of bladder cancer. Adv Funct Mater 24: 6601-6611, 2014.

32. Miao L, Wang Y, Lin CM, Xiong Y, Chen N, Zhang L, Kim WY and Huang L: Nanoparticle modulation of the tumor microenvironment enhances therapeutic efficacy of cisplatin. J Control Release 217: 27-41, 2015.

33. Green HN, Martyshkin DV, Rosenthal EL and Mirov SB A minimally invasive multifunctional nanoscale system for selective targeting, imaging, and NIR photothermal therapy of malignant tumors. In: Proceedings of the Reporters, Markers, Dyes, Nanoparticles, and Molecular Probes for Biomedical Applications III. Vol 7910. SPIE BiOS, San Francisco, CA, 2011

34. Green HN, Crockett SD, Martyshkin DV, Singh KP, Grizzle WE, Rosenthal EL and Mirov SB: A histological evaluation and in vivo assessment of intratumoral near infrared photothermal nanotherapy-induced tumor regression. Int J Nanomedicine 9: 5093-5102, 2014

35. Sebaugh JL: Guidelines for accurate EC50/IC50 estimation. Pharm Stat 10: 128-134, 2011.

36. Guo S, Lin CM, Xu Z, Miao L, Wang Y and Huang L: Co-delivery of cisplatin and rapamycin for enhanced anticancer therapy through synergistic effects and microenvironment modulation. ACS Nano 8: 4996-5009, 2014.

37. Zhou F, Feng B, Yu H, Wang D, Wang T, Liu J, Meng Q, Wang S, Zhang $\mathrm{P}$, Zhang Z and $\mathrm{Li}$ Y: Cisplatin prodrug-conjugated gold nanocluster for fluorescence imaging and targeted therapy of the breast cancer. Theranostics 6: 679-687, 2016

38. Hackenberg S, Scherzed A, Harnisch W, Froelich K, Ginzkey C, Koehler C, Hagen R and Kleinsasser N: Antitumor activity of photo-stimulated zinc oxide nanoparticles combined with paclitaxel or cisplatin in HNSCC cell lines. J Photochem Photobiol B 114: 87-93, 2012.

39. Hackenberg S, Scherzed A, Kessler M, Froelich K, Ginzkey C, Koehler C, Burghartz M, Hagen R and Kleinsasser N: Zinc oxide nanoparticles induce photocatalytic cell death in human head and neck squamous cell carcinoma cell lines in vitro. Int J Oncol 37: 1583-1590, 2010.

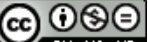

This work is licensed under a Creative Commons Attribution-NonCommercial-NoDerivatives 4.0 International (CC BY-NC-ND 4.0) License. 